\title{
NEW THERAPEUTIC CONCEPTS IN POST-RESUSCITATION CARE
}

\author{
Jasna Jevdjic ${ }^{1,3}$, Filip Zunic ${ }^{1,3}$, Bojan Milosevic ${ }^{2,3}$
}

${ }^{1}$ Department for anesthesia and ranimation, Clinical Centre Kragujevac, Kragujevac, Serbia

${ }^{2}$ Clinic for Chirurgy, Clinical Centre Kragujevac, Kragujevac, Serbia

${ }^{3}$ Faculty of Medical Sciences, Kragujevac, Serbia

\author{
NOVI TERAPIJSKI KONCEPTI \\ U POSTRESUSCITACIONOM LEČENJU \\ Jasna Jevđić1, ${ }^{1,3}$ Filip Žunić1,3, Bojan Miloševićc ${ }^{2,3}$ \\ ${ }^{1}$ Služba za anesteziju i reanimaciju KC Kragujevac \\ ${ }^{2}$ Klinika za hirurgiju, KC Kragujevac \\ ${ }^{3}$ Fakultet medicinskih nauka, Kragujevac
}

\begin{abstract}
After the return of spontaneous circulation (ROSC), as a result of global ischaemia due to cardiac arrest followed by reperfusion, a condition develops called post-cardiac arrest syndrome. It manifests, alongside the pathology that caused the cardiac arrest, as a systemic inflammatory response, including severe cardio-circulatory and neurological dysfunction, leading to a fatal outcome. The aim of post-resuscitation care is to reduce the consequences of circulatory arrest, reperfusion, and the inflammatory response of the body on vital organ functions. The basis of post-resuscitation care comprises application of therapeutic hypothermia and early coronary angiography with PCI. However, after the initial enthusiasm, the validity of applying these aggressive methods in all comatose post-cardiac arrest patients was questioned. Currently, instead of therapeutic hypothermia, a strategy of maintaining a targeted body temperature, usually $36{ }^{\circ} \mathrm{C}$, is being applied because there is no clear evidence of benefit for maintaining a lower body temperature in relation to the outcome. Additionally, patients with an obvious cardiac aetiology of cardiac arrest do not undergo early coronarography unless there is a clear indication of coronary artery occlusion. In the post-resuscitation period, the maintenance of adequate ventilation, maintaining levels of oxygen and carbon dioxide in the normal range, haemodynamic stability, control of blood glucose and electrolytes, and epileptic attack prevention are all strongly recommended measures. There is no evidence to suggest that the application of the so-called neuroprotective agents affects the outcome of cardiac arrest.
\end{abstract}

Keywords: heart failure, outcome, post-resuscitation care, therapeutic hypothermia, percutaneous coronary intervention

\section{SAŽETAK}

Nakon povratka spontane cirkulacije (ROSC), kao posledica globalne ishemije usled srčanog zastoja, a potom reperfuzije, dolazi do razvoja Post-cardiac arrest sindroma. On se manifestuje sistemskim inflamatornim odgovorom organizma, teškom kardiocirkulatornom $i$ neurološkom disfunkcijom, uz prisutnu patologiju koja je dovela do srčanog zastoja, sto vodi smrtnom ishodu. Cilj postresuscitacionog lečenja je da smanji posledice prestanaka cirkulacije/reperfuzije i inflamatornog odgovora organizma na funkcionisanje vitalnih organa. Osnovu postresuscitacionog lečenja činili su primena terapijske hipotermije i rane koronarografije sa PCI. Međutim, nakon početne euforije, dovedena je u sumnju opravdanost primene ovih agresivnih metoda kod svih komatoznih pacijenata nakon srčanog zastoja. Danas se umesto terapijske hipotermije primenjuje strategija održavanja ciljane telesne temperature, uobičajeno $36^{\circ} \mathrm{C}$, jer nema jasnih dokaza o benefitu održavanja nižih telesnih temperatura u odnosu na ishod. Takode se rana koronarografija ne primenjuje više kod svih pacijenata nakon srčanog zastoja očigledne kardijalne etiologije, već samo ukoliko postoji jasna sumnja na okluziju koronarnih arterija. U post-resustitacionom periodu se takode snažno preporučuje održavanje adekvatne ventilacije, uz održavanje kiseonika $i$ ugljen dioksida u krvi u okvru normalnih vrednosti, hemodinamske stabilnosti, kontrola glikemije, elektrolitnog statusa i sprečavanje epi-napada. Nema dokaza da primena tkz. neuroprotektivnih lekova utiče na ishod srčanog zastoja.

Ključne reči: srčani zastoj, ishod, post-resuscitaciono lečenje, terapijkk hipotermija, perkutana koronarna intervencija 


\section{INTRODUCTION}

The leading cause of death in Europe is out-of-hospital cardiac arrest (1). During the last decade, there has been significant progress in pre-hospital resuscitation, and a significant increase in the percentage of patients arriving to the hospital with re-established heartbeats after cardiac arrest. However, the ultimate outcome of cardiac arrest is still poor. Approximately $25-35 \%$ of patients with out-of-hospital cardiac arrest experience a return of spontaneous circulation (ROSC) after cardiopulmonary resuscitation (CPR), while the percentage of survivors discharged from the hospital is approximately $10 \%$. However, the percentage of survivors with good neurological outcomes is even lower (2). It is clear that to improve the prognosis of cardiac arrest, in addition to measures related to the improvement of prehospital resuscitation and informing the community about the basics of CPR, emphasis should be placed on post-resuscitation care. For a good end result following cardiac arrest, it is necessary to provide adequate protocol- and team-based continuation of treatment for these patients in the hospital.

After the return of spontaneous circulation, following a period of global hypoxia and ischaemia that occur due to cardiac arrest with compensatory processes, there is further reperfusion damage. Ischaemia / reperfusion injury occurs as a consequence of complex processes happening as a result of the synthesis and release of a number of inflammatory cytokines, activation of the complement cascade, haemotaxis and activation of polymorphonuclear leukocytes. The consequences of these processes are platelet activation, intravascular coagulation, endothelial damage and increased vascular permeability. Intracellular anoxia leads to disruption of oxidative phosphorylation in the mitochondria, thereby starting the process of anaerobic glycolysis, and subsequently resulting in an increase in lactate levels and intracellular acidosis with further electrolyte disorders (3). These complex events are actually a form of systemic inflammatory response syndrome (SIRS) of the organism, which leads to progressive destruction of the cells and multiple organ dysfunction, a condition known as post-cardiac arrest syndrome. Post-resuscitation care should be aimed at minimizing post-cardiac arrest syndrome. According to the treatment recommendations of the International Liaison Committee on Resuscitation (ILCOR) from 2015 (4), besides maintaining the target temperatures (targeted temperature management), the most important goals of post-resuscitation care are early treatment of the causes of cardiac arrest, haemodynamic stabilization, adequate oxygenation and ventilation, and regulation of blood glucose and electrolyte status.

\section{TARGET TEMPERATURE MANAGEMENT}

The application of therapeutic hypothermia after cardiac arrest leads to a reduction of cerebral metabolism with the preservation of high-energy phosphate reserves and reduced release of inflammatory cytokines and excitatory amino acids. Additionally, there is a stabilization of the endothelial membrane and reduction of brain edema after the application of therapeutic hypothermia. Two published, randomized, prospective, controlled trials have shown improved survival and improved neurological outcomes following the application of therapeutic hypothermia after VF in out-of-hospital cardiac arrest $(5,6)$. Afterwards, in the 2010 ERC cardiopulmonary guidelines, therapeutic hypothermia was highly recommended in post-resuscitation care. The 2010 guidelines state that patients should be cooled at $32-34{ }^{\circ} \mathrm{C}$ for a duration of $12-24$ hours. Cooling should start as soon as possible, even before arriving at the hospital, if possible. However, two recently published randomized, controlled studies challenge this approach.

In the first of these studies, published in JAMA (7), which included 1,359 patients, the authors showed that pre-hospital cooling with 2 litres of $4{ }^{\circ} \mathrm{C}$ saline immediately after ROSC led neither to increased survival upon discharge from the hospital nor to better neurological outcomes compared to the group of patients cooled at the moment of hospital admission. However, in this group of patients, there were significantly more repeated cardiac arrests in the field, as well as more frequent pulmonary oedemas on the first chest radiography. Diao came to the same conclusion in his meta-analysis of 5 randomized, controlled studies that included a total of 633 patients (8).

Another important multicenter, randomized study (9) included 939 unconscious patients after out-of-hospital cardiac arrest. Patients were randomized in two groups: patients whose body temperature was maintained at $33^{\circ} \mathrm{C}$ and a group of patients whose body temperature was maintained at $36{ }^{\circ} \mathrm{C}$. Among the groups there was no statistically significant difference in survival and neurological outcome. After the follow-up period of 180 days, in the group maintained at $33{ }^{\circ} \mathrm{C}$, $54 \%$ of patients died or had poor neurological outcomes according to the CPC (Cerebral Performance Category) scale compared to $52 \%$ of patients with a fatal outcome in the group maintained at $36{ }^{\circ} \mathrm{C}$.

This research indicates that, for a good outcome, it is sufficient to maintain the target body temperature within certain limits and to prevent fever during the first 3 days after cardiac arrest; therefore, it is not necessary to cool down patients to $32-34{ }^{\circ} \mathrm{C}$. We should not forget that hypothermia affects all organ systems, which can lead to unintended consequences in some patients; therefore, it would be better to apply a less aggressive approach. Numerous studies show that hyperthermia is to blame for the poor outcome of cardiac arrest, whether it occurs after application of therapeutic hypothermia (rebound pyrexia) or in patients who are not cooled $(10,11,12,13)$.

The 2015 ERC recommendations for cardiopulmonary resuscitation state that it is necessary to maintain a target body temperature between $32{ }^{\circ} \mathrm{C}$ and $36{ }^{\circ} \mathrm{C}$. 


\section{CORONARY ANGIOGRAPHY AND PCI}

Removing causes that lead to cardiac arrest is an important segment of post-resuscitation treatment because it significantly reduces the probability of cardiac arrest recurrence and worsening of the disease. In the case of cardiac arrest caused by myocardial infarction with ST-segment elevation (STEMI), the ERC 2015 guidelines strongly recommend urgent (within $90 \mathrm{~min}$ ) coronary angiography and, if necessary, percutaneous coronary intervention (PCI), which would enable myocardial reperfusion and thus preservation of myocardial contractility and improved perfusion of the brain. There are no randomized clinical studies to confirm the benefits of this approach, but on the basis of numerous observational studies, it was concluded that the urgent PCI in STEMI doubles the chances for survival and contributes to good neurological outcomes (14).

However, there is a dilemma concerning what to do when there is no ST-segment elevation in an ECG obtained after cardiac arrest. The absence of ST-segment elevation and symptoms of acute coronary syndrome after resuscitation are not solid proof that there is no significant occlusion of the coronary arteries. In patients who had out-of-hospital cardiac arrests with cardiac aetiologies, the incidence of coronary artery occlusion is very high, even when there is no ST-segment elevation present in the post-cardiac arrest ECG. If every patient were to undergo emergency coronary angiography after cardiac arrest, regardless of whether they have obvious clinical and ECG signs of coronary artery disease, it would enable early myocardial revascularization and all the clinical benefits that it brings in cases with coronary artery occlusion. On the other hand, such a non-selective approach would expose patients who had no occlusive disease to a very invasive and potentially dangerous procedure that is unnecessary. Randomized controlled trials that assess the effects of the implementation of early coronary angiography and PCI in patients with cardiac arrest without ST-segment elevation do not exist, and the results of retrospective observational studies are contradictory. Some of these studies show that early coronary angiography and PCI increase survival (15, $16,17)$, while others report no benefits from these methods in patients in whom there are not clear signs of coronary occlusion (18).

\section{CARDIOVASCULAR STABILIZATION}

Cardiovascular instability is common after cardiac arrest. It usually resolves spontaneously after 48-72 hours (19), but it is associated with poor neurological outcomes in survivors. Therefore, it is necessary to maintain an adequate mean arterial pressure (MAP) during the post-resuscitation period. Target blood pressure during the post-resuscitation period is not precisely defined, but it must be sufficient to ensure good brain perfusion, whose auto-regulatory mechanisms are disturbed during this period. In addition to not being low, blood pressure also should not be too high because it increases myocardial work and myocardial oxygen demands. Stabilization of the cardiovascular system is achieved by fluid replacement and the use of inotropic and vasoactive drugs. In experimental animal models, dobutamine showed the best effects on improving cardiac systolic and diastolic function after a cardiac arrest. Tests of other inotropic and vasoactive drugs did not demonstrate comparative advantages in relation to dobutamine (20). The combination of dobutamine and noradrenaline was shown to be especially good. When drug therapy is not effective, mechanical support, such as an intra-aortic balloon pump, can be used. In severe ventricular failure, mechanical support often is not sufficient. In these cases, a percutaneous cardiopulmonary bypass with extracorporeal oxygenation can be used. Currently, there are available portable extracorporeal blood oxygenators, whose application is possible in the field in the cases of long-lasting resistant cardiac arrest $(21,22.23)$.

Hemodynamic monitoring (heart rate, blood pressure, cardiac output, $\mathrm{SvO} 2$ or $\mathrm{ScvO} 2$, lactate and arterial gas analysis) is required to achieve the optimization of circulation and adequate oxygen delivery to tissues.

\section{VENTILATION AND OXYGENATION}

Experimental studies in animals have shown that hyperoxia after ROSC promotes the production of reactive oxygen species, which leads to oxygenation of lipids and proteins and disrupts the integrity of cell membranes and normal enzyme activities. Ultimately, hyperoxia leads to greater neuronal damage and poor neurological outcomes. Large multicenter, retrospective, cohort studies have shown that patients who have been hyperoxic in the post-resuscitation period had significantly higher mortality compared to normoxic and even hypoxic patients (24, 25). In the post-resuscitation period, the percentage of inspired oxygen should be adjusted to maintain oxygen saturation at $94-98 \%$, and not above these values.

Hypocapnia and hypercapnia are common after ROSC, and both are associated with poor neurological outcomes (26). Therefore, maintenance of normocapnia is recommended during post-resuscitation care.

\section{METABOLIC CONTROL}

Because of the neurogenic and endocrine responses to stress after cardiac arrest, in the period after ROSC, hyperglycaemia is a common finding. Although numerous studies suggest a connection between hyperglycaemia and death in critically ill patients, strict glycemic control in patients after cardiac arrest cannot be recommended. In this group of critically ill patients, hypoglycaemia has a much worse effect on the neurological outcome than hyperglycaemia; therefore, it must be avoided at all costs. For 
that reason, the concept of intensive insulin therapy has been abandoned (27). Variations in the levels of blood glucose have unfavourable effects on these patients and they should be avoided (28). The level of blood glucose should be measured frequently, especially when a patient is in therapeutic hypothermia. It is sufficient to maintain glycaemia below $10 \mathrm{mmol} / \mathrm{l}$.

Electrolyte imbalance is also possible and should be avoided, especially because it might lead to a cardiac arrest. Magnesium levels in the blood should also be taken into account because magnesium affects the functioning of the central nervous and cardiovascular systems, as well as the levels of other electrolytes in the blood.

\section{CONCLUSION}

The outcome of cardiac arrest largely depends on the speed of establishing and maintaining circulation. Education of specific target groups of the population and telephone-guided CPR contributed to a higher percentage of high-quality chest compressions administered immediately after cardiac arrest. Timely CPR and the increased availability of automated external defibrillators in public places have increased the rate of initial survival after cardiac arrest. To increase long-term survival with good neurological outcomes, it is necessary to treat the complications of post-cardiac arrest syndrome and provide neuroprotection.

Implementation of measures to maintain target temperature, urgent coronary angiography and PCI, maintenance of haemodynamic and metabolic homeostasis, and adequate oxygenation and ventilation are the most important treatment modalities of post-resuscitation care.

\section{REFERENCES}

1. Atwood C, Eisenberg MS, Herlitz J, Rea TD. Incidence of EMS-treated out-of-hospital cardiac arrest in $\mathrm{Eu}$ rope. Resuscitation 2005; 67:75-80.

2. Nurnberger A, Sterz F, Malzer R, et al. Out of hospital cardiac arrest in Vienna: Incidence and outcome. Resustitation 2013; 84:42-47.

3. Adrie C, Adib-Conquy M, Laurent I et al. Successful cardiopulmonary resuscitation after cardiac arrest as a "sepsis-like" syndrome. Circulation 2002;106:562-8.

4. Nolan JP, Soar J, Cariou A, Cronberg T, Moulaert V, et al. European Resuscitation Council and European Society of Intensive Care Medicine Guidelines for Post-resuscitation Care 2015. Resuscitation 2015; $\overline{95}: 202-222 \mathrm{R}$.

5. The Hypothermia Afther Cardiac Arrest (HACA) study group: Mild therapeutic hypothermia to improve the neurologic outcome after cardiac arrest. New England Journal of Medicine 2002; 346:549-56.

6. Bernard SA, Gray TW, Buist MD, et al. Treatment of comatose survivors of out-of-hospital cardiac arrest with induced hypothermia. New England Journal of Medicine 2002; 346:557-63.

7. Kim F, Nichol G, Maynard C, et al. Effect of prehospital induction of mild hypothermia on survival and neurological status among adults with cardiac arrest: A randomized clinical trial. JAMA 2014; 311(1):45-52.

8. Diao M, Huang F, Guan J, et al. Prehospital therapeutic hypothermia after cardiac arrest: a systematic review and meta -analysis of randomized controlled trials. Resuscitation 2013;84:1021-8.

9. Nielsen N, Wetterslev J, Cornberg T, et al. Targeted temperature management at $33^{\circ} \mathrm{C}$ versus $36^{\circ} \mathrm{C}$ after cardiac arrest. N Engl J Med 2013; 369:2197-206.

10. Leary M, Grossestreuer AV, Iannacone S, et al. Pyrexia and neurologic outcomes after therapeutic hypothermia for cardiac arrest. Resuscitation 2013;84:1056-61.

11. Gebhardt K, Guyette FX, Doshi AA, Callaway CW, Rittenberger JC, Post Cardiac Arrest Service. Prevalence and effect of fever on outcome following resuscitation from cardiac arrest. Resuscitation 2013;84:1062-7.

12. Bro-Jeppesen J, Hassager C, Wanscher M, et al. Post -hypothermia fever is associ- ated with increased mortality after out -of-hospital cardiac arrest. Resuscitation 2013;84:1734-40.

13. Winters SA, Wolf KH, Kettinger SA, Seif EK, Jones JS, Bacon -Baguley T. Assessment of risk factors for postrewarming "rebound hyperthermia" in cardiac arrest patients undergoing therapeutic hypothermia. Resuscitation 2013;84:1245-9.

14. Garot P, Lefevre T, Eltchaninoff H, et al. Six-month outcome of after emergency percutaneous coronary intervention in resuscitated patients cardiac arrest complicating ST-elevation myocardial infarction. Circulation 2007; 115:1354-1362.

15. Dumas F, Cariou A, Manzo-Silberman S, Grimaldi D, Vivien B, Rosencher J, Empana J-P, Carli P, Mira J-P, Jouven $X$, Spaulding C. Immediate percutaneous coronary intervention is associated with better survival after out-of-hospital cardiac arrest: insights from the PROCAT (Parisian Region Out of hospital Cardiac ArresT) registry. Circ Cardiovasc Interv 2010; 3:200-207.

16. Larsen JM, Ravkilde J. Acute coronary angiography in patients resuscitated from out-of-hospital cardiac arrest-a systematic review and meta-analysis. Resuscitation 2012; 83:1427-1433.

17. Hollenbeck RD, McPherson JA, Mooney MR, et al. Early cardiac catheterization is associated with improved survival in comatose survivors of cardiac arrest without STEMI. Resuscitation 2014; 85:88-95.

18. Bro-Jeppesen J, Kjaergaard J, Wanscher M, Pedersen F, Holmvang L, Lippert F, Møller J, Køber L, Hassager C. Emergency coronary angiography in comatose cardiac arrest patients: do real-life experiences support the guidelines? Eur Heart J Acute Cardiovasc Care 2012; 1:291-301. 
19. Laurent I, Monchi M, Chiche JD, et al. Reversible myocardial dysfunction in survivors of out-of-hospital cardiac arrest. J Am Coll Cardiol 2002; 40: 2110-6.

20. Huang L, Weil MH, Tang, W, et al.Comparison between dobutamine and levosimendan for management of postresuscitation myocardial dysfunction. Crit Care Med 2005; 33:487-491.

21. Fagnoul D, Taccone FS, Belhaj A, et al. Extracorporeal life support associated with hypothermia and normoxemia in refractory cardiac arrest. Resuscitation 2013; 84:1519-24.

22. Wallmuller C, Sterz F, Testori C, et al. Emergency cardio -pulmonary bypass in cardiac arrest: seventeen years of experience. Resuscitation 2013; 84:326-30.

23. Muller T, Lubnow M. The future of E-CPR: a joint venture. Resuscitation 2013;84:1463-4.

24. Kilgannon JH, Jones AE, Shapiro NI, et al. Emergency Medicine Shock Research Network (EMShockNet) Investigators. Association between arterial hyperoxia fol- lowing resuscitation from cardiac arrest and in-hospital mortality. JAMA 2010; 303: 2165-71

25. Kilgannon JH, Jones AE, Parrillo JE,et al. Emergency Medicine Shock Research Network (EMShockNet) Investigators. Relationship between supranormal oxygen tension and outcome after resuscitation from cardiac arrest. Circulation 2011;123:2717-2722.

26. Roberts B, Kilgannon H, Chansky M, et al. Association between postresuscitation partial pressure of arterial carbon dioxide and neurological outcome in patients with post cardiac arrest syndrome. Circulation 2013; 127:2107-2113.

27. Beiser D, David G, Gordon E, et al. Derangements in blood glucose following initial resuscitation from in-hospital cardiac arrest: A report from the national registry of cardiopulmonary resuscitation. Resuscitation 2009;80(6):624-630.

28. Cueni-Villoz N, Devigili A, Dellodder F, et al. Increased blood glucose variability during therapeutic hypothermia and outcome after cardiac arrest. Crit Care Med 2011; 39:2225-2231. 